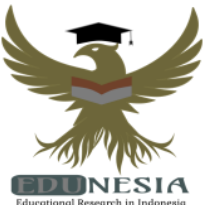

\title{
The Efforts to Increase Teachers' Competence in Establishing KKM Through Training Activities MTS Daarul Muhsinin Janji Manahan Kawat Kabupaten Labuhanbatu
}

\author{
Hasan Basri \\ Madrasah Education Supervisor, Kab. Labuhan Batu, Indonesia \\ Corresponding Email: hasanbsb8@gmail.com, Phone Number:0813 xxxx xxxx
}

\begin{abstract}
Article History:
Received: July 22, 2021

Revised: Sept 20, 2021

Accepted: Sept 21, 2021

Online First: Okt 04, 2021
\end{abstract}

\section{Keywords:}

Minimum Completeness

Criteria,

Teachers' Competence,

Training Activities.

Kata Kunci:

Aktivitas Pelatihan,

Kompetensi Guru,

Kriteria Ketuntasan

Minimal (KKM).

\section{How to cite:}

Basri, H. (2021). The Effort to

Increase Teachers

Cmpetence in Establlishing

KKM Through Training

Activities MTS Daarul

Muhsinin Janji Manahan

Kawat Kab. Labuhanbatu.

Edunesia: Jurnal Ilmiah

Pendidikan, 2 (3): 685-695.

This is an open access article under the CC-BY-NC-ND license (c) $(9)$
Abstract: KKM is the target of the education unit in achieving the competence of each subject. The education unit must make every effort to exceed the specified KKM. The success of achieving KKM is one of the benchmarks for the performance of the education unit in implementing educational programs. Education units with a high KKM and implemented responsibly can be a benchmark for the quality of education for the community. Therefore, there needs to be activities that can improve teacher competence in compiling KKM so that KKM in schools can really be measured and accounted. The method in this research is the action research method (action research). This study uses a qualitative approach. The subject of the study was the teacher of MTs Daarul Muhsinin in the area of the Ministry of Religion Office of Labuhan Batu Regency. The number of teachers who participated in this activity was 29 people. The results of the first cycle activities still cannot be said to be successful, this is because the average score of the teachers is still below 50 or less. In the second cycle, the training activities were followed up by providing practical assistance, in which the researcher and participants jointly set the minimum completeness criteria. In the second cycle, the results of determining the minimum completeness criteria for subjects prepared by the teacher increased sharply, this was evidenced by the teachers getting an average score of 85 or good. From the results of the study it can be concluded that there is an increase in teacher competence in determining minimum completeness criteria. In the first cycle the average teacher competency score was 25 or less, then increased to 85 or good. This means that training activities have a positive impact on increasing teacher competence in determining minimum completeness criteria.

Abstrak: KKM merupakan target satuan pendidikan dalam pencapaian kompetensi tiap mata pelajaran. Satuan pendidikan harus berupaya semaksimal mungkin untuk melampaui KKM yang ditetapkan. Keberhasilan pencapaian KKM merupakan salah satu tolok ukur kinerja satuan pendidikan dalam menyelenggarakan program pendidikan. Satuan pendidikan dengan KKM yang tinggi dan dilaksanakan secara bertanggung jawab dapat menjadi tolok ukur kualitas mutu pendidikan bagi masyarakat. oleh karena itu, perlu ada kegiatan yang dapat meningkatkan kompetensi guru dalam menyusun KKM sehingga KKM yang ada disekolah itu benar-benar dapat terukur dan dipertanggungjawabkan. Metode dalam penelitian ini yaitu metode penelitian tindakan (action research). Penelitian ini menggunakan pendekatan kualitatif. Subjek penelitian adalah guru MTs Daarul Muhsinin di wilayah Kantor Kementerian Agama Kabupaten Labuan Batu. Jumlah guru yang mengikuti kegiatan ini adalah 29 orang. Hasil dari kegiatan siklus pertama masih belum dapat dikatakan berhasil, hal ini disebabkan peroleh rata-rata sekor para guru masih di bawah 50 atau kurang. Pada siklus kedua, kegiatan pelatihan ditindaklanjuti dengan memberikan bantuan praktis, di mana peneliti dan peserta secara bersama-sama menetapkan kriteria ketuntasan minimal. Pada siklus kedua, hasil menetapkan kriteria ketuntasan minimal mata pelajaran yang disusun oleh guru meningkat tajam, hal ini dibuktikan dengan peroleh rata-rata sekor para guru sebesar 85 atau baik. Dari hasil penelitian dapat disimpulkan bahwa terjadi peningkatan kompetensi guru dalam menetapkan kriteria ketuntasan minimal. Pada siklus pertama sekor rata-rata kompetensi guru adalah 25 atau kurang, kemudian meningkat menjadi 85 atau baik. Artinya kegiatan pelatihan memberikan dampak positif terhadap peningkatan kompetensi guru dalam menetapkan kriteria ketuntasan minimal. 


\section{A. Introduction}

The learning process in madrasah can be optimized in various ways, one of which is through directed and sustainable coaching (Mispandi \& Widayati, 2021). The program implemented must be measurable and systematic, the main target of which is education implementers at the madrasah level (Setiyadi \& Rosalina, 2021). Madrasah supervisors and principals are leaders in the field of education who contribute to the development and sustainability of education in a madrasah (Zaini \& Syafaruddin, 2020).

Supervisors and principals of madrasah carry out supervision in order to increase the activity, effectiveness, and efficiency of an academic activity (Wahyu, 2020). The progress of madrasa also cannot be separated from the managerial competence possessed by the madrasa head. In education management, the madrasah principal has a role in the creation of a quality culture in the educational unit he is leading.

Supervisors have the authority to assist in monitoring, fostering, evaluating the implementation of the duties of teachers and principals (DiPaola \& Wagner, 2018). Recommendations resulting from the evaluation have the right to be issued by the supervisor on the performance of the principal to be shown to the head of service and local government as a follow-up to the results of supervision. Supervisors are not people who have the authority to execute on the results of teacher performance assessments. This means that supervisors are partners with principals and teachers to improve the quality of learning.

Decree of the Minister of State for Administrative Reform (Kep. MENPAN) No. 118/1996 and the Decree of the Minister of Religion (KMA) No. 381/1999 is the supervisor's handbook in coaching activities whose contents are school supervisors/religious education supervisors are civil servants who are given full duties, responsibilities and authorities by authorized officials to supervise the implementation of religious education/education in public schools and madrasah with carry out assessment and guidance in terms of technical education and administration in preschool education units, primary and secondary schools.

Teacher professionalism can be measured by referring to the Law of the Republic of Indonesia No. 14 of 2005 which discusses Teachers and Lecturers in CHAPTER IV Article 20. In this Law it is explained that in carrying out their duties, teachers are obliged to: 1) Make lesson plans, carry out the learning process, as well as assess and evaluate learning outcomes, 2) Continuously improve academic qualifications and competencies in line with the development of science and technology and the arts 3) Act objectively and non-discriminatory on the basis of considerations of gender, religion, ethnicity, race, and certain physical conditions or family background, and socioeconomic status of students in learning, 4) Upholding laws and regulations, laws, and codes of ethics for teachers, as well as religious and ethical values, 5) Maintaining and fostering national unity and integrity.

A teacher must always improve his professional abilities, knowledge, attitudes, and skills continuously according to the development of science and technology, including the new paradigm of education that applies School/Madrasah Based Management (MBS/M) and the K13 Curriculum. According to the Directorate General of Primary and Secondary Education, Ministry of National Education (2004:2), a teacher must meet three competency standards, including: (1) learning management 
competence and educational insight, (2) academic/vocational competence according to learning materials, (3) professional development. These three competencies aim to make quality teachers to make quality learning as well, which ultimately improves the quality of Indonesian education.

To achieve these three competencies, schools must carry out coaching for teachers through training, workshops, PKG, discussions, and supervision either by the principal or supervisor. This must be done periodically so that the competence and insight of teachers, especially MTs teachers in the Labuhan Batu Regency area increase at any time in accordance with the development of science and technology. According to Samidi (2019), in general there are several factors that cause the current low competence and insight of teachers, namely: (1) low awareness of teachers to learn, (2) lack of opportunities for teachers to participate in training, both regionally and nationally, (3) the ineffectiveness of MGMP/KKM. To improve the competence and insight of teachers in learning, it is necessary to conduct school action research with the above problems. Due to various limitations, this research is only focused on academic supervision activities, especially group supervision techniques on teacher competence in compiling Minimum Completeness Criteria (KKM).

Based on the background of the problem above, the formulation of this research is: "Can teachers improve their competence through training activities in determining KKM according to their respective subjects?

\section{B. Method}

The method in this research is the action research method (action research). This study uses a qualitative approach. The subject of the research was the teacher of MTsS Daarul Muhsinin in the area of the Ministry of Religion Office of Labuhan Batu Regency. The number of teachers who participated in this activity was 29 people. The activity was carried out at MTs Daarul Muhsinin, Janji Manahan Kawat, Tanjung Siram Village, Bilah Hulu District, Labuhan Batu Regency. The research lasts for 3 days, from 3 - 5 June 2021. Action research is included in the scope of applied research which combines knowledge, research and action. Data obtained from collecting data in a participatory (participative observation). This technique is an observation activity where participants and researchers participate to feel the natural symptoms that occur. Observations were carried out either systematically (systematic observation) which had been designed since the beginning of the study or non-systematic observation (non-systematic observation) which was obtained accidentally. While the instrument used is an academic supervision instrument to determine the minimum completeness criteria used by supervisors in supervision activities. The instrument consists of a column of assessed aspects, operational indicators and an assessment in the form of observation sheets and tests. To make the flow of this research clearer, it can be seen in Figure 1 below: 


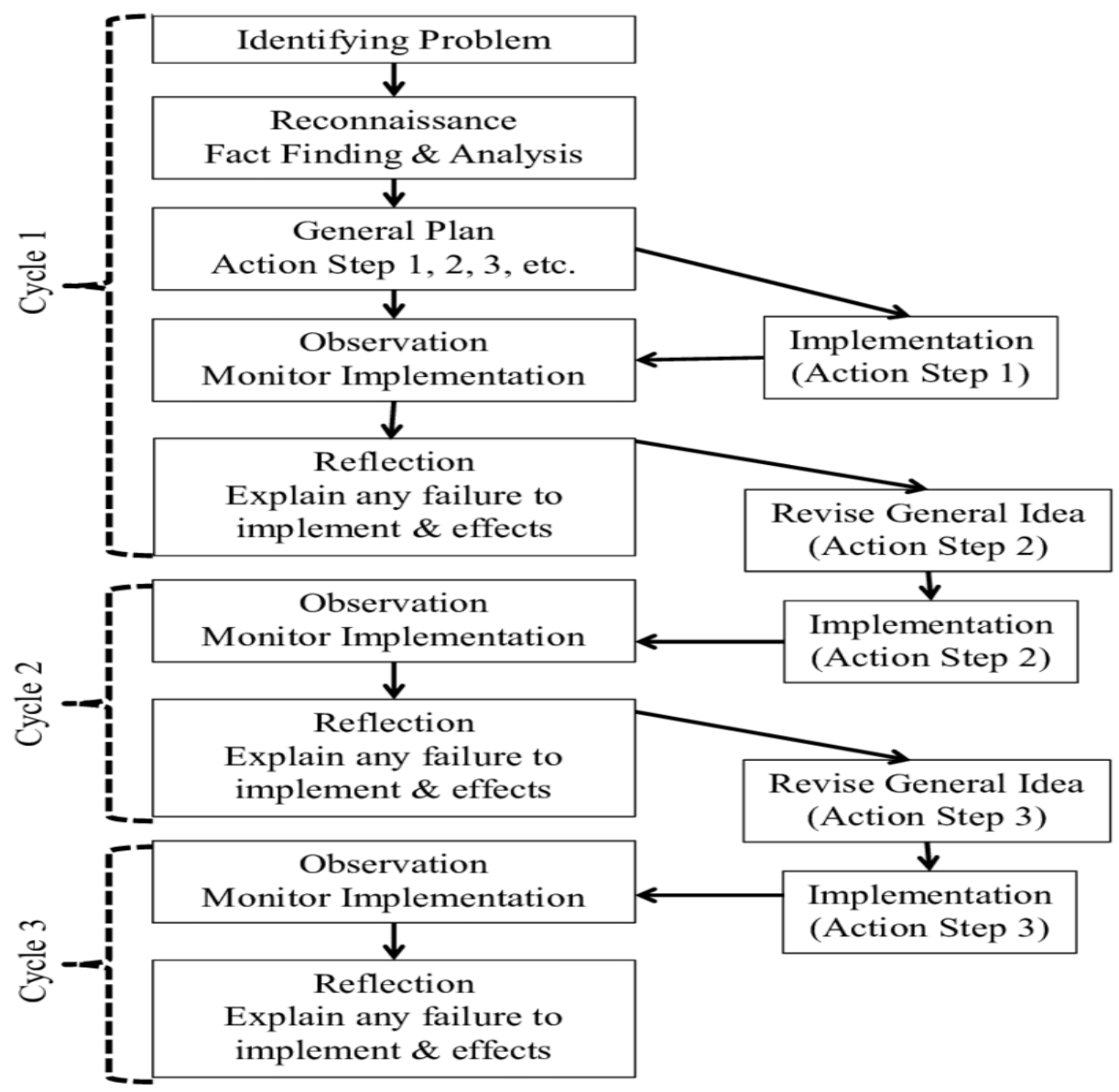

Figure 1. Class Action Research Method

\section{Result and Discussion}

\section{Description of research results}

a) Description of Initial conditions

Before this school action research was carried out, the researchers conducted and collected data by observing the initial conditions of the class that would be given the action.

This initial knowledge needs to be known so that this research is in accordance with what is expected by the researcher, is it true that this class needs to be given actions that are in accordance with the planned training strategy. To obtain data on the real condition of the supervisor, take the following steps:

1. Planning.

To find out the initial conditions, the researchers planned to conduct direct learning observations. Observation of the implementation of learning is done to find out the training strategy that researchers use in providing material on Minimum Completeness Criteria (KKM). 


\section{Implementation.}

The implementation to measure the initial ability of teachers is carried out on Thursday, June 3, 2021. At this implementation stage, researchers supervise the work of teachers in compiling the Minimum Completeness Criteria (KKM) given, so that the accuracy of the research results can be accounted for.

\section{Observations.}

Based on observations made by researchers, it was found that in the activities of compiling Minimum Completeness Criteria (KKM), teachers still did not fully understand how to prepare Minimum Completeness Criteria (KKM). In this activity, it was seen that there were still teachers who asked left and right to friends sitting next to them.

After the results of the work of compiling the Minimum Completeness Criteria (KKM) were collected and the researchers immediately corrected them, the results were unsatisfactory. From the results of the initial correction, there are still many teachers who do not know how to formulate Minimum Completeness Criteria (KKM). Only 10\% of teachers know how to prepare Minimum Completeness Criteria (KKM) through similar training that they have attended.

\section{Reflection.}

From these initial conditions, it is necessary to take an action to raise the ability of teachers in compiling Minimum Completeness Criteria (KKM) at MTsS Daarul Muhsinin, Labuhan Batu Regency, North Sumatera Province.

Starting from these initial conditions, the researchers planned research actions by applying training strategies to the provision of material for the preparation of Minimum Completeness Criteria (KKM).

b) Description of Cycle I.

1. Planning. include:

To conduct research in cycle I, researchers and teaching teachers plan actions that

1) Make a syllabus of learning materials.

2) Designing teaching programs. The program design created is used for teaching $2 \times 40$ minutes with details (1) 5 minutes of apperception (2) The core activity consists of working on worksheets and activating students with the question and answer method for 50 minutes (3) Closing 5 minutes (4) evaluation of 20 minutes.

3) Create a teacher worksheet that is used to activate the teacher in compiling the Minimum Completeness Criteria (KKM) with a step-by-step arrangement that leads the teacher to problem finding or solving a problem. 
4) Create an evaluation tool that is used to obtain data on the ability of teachers in compiling Minimum Completeness Criteria (KKM), after receiving action using training strategies.

5) Make solutions and steps to convey to the teacher regarding the teacher's weaknesses in solving problems.

2. Implementation of Actions.

The implementation of the actions in the first cycle was carried out on Saturday, June 5, 2021, the researchers carried out activities according to what had been planned, starting with an explanation to the teacher about the activities that the teacher had to do in participating in the activity.

Based on the information that has been obtained by the researcher during the observation of the preparation of the Minimum Completeness Criteria (KKM) carried out by the teacher, the researcher conveys the weaknesses and shortcomings made by the teacher in completing the preparation of the Minimum Completeness Criteria (KKM).

Furthermore, the researchers distributed worksheets that had been designed by the researchers to be completed by the teacher as a whole and the researchers went around to observe how the teacher worked and help teachers who had problems in completing the distributed worksheets.

During the implementation of completing the teacher's worksheet, several teachers communicated with their closest friends about how to complete the distributed worksheets. While walking around the researcher noted the obstacles that occurred when the teacher worked on the worksheet. In addition, the researchers also noted teachers who were active and able to solve the problems given by the researchers.

The researcher ordered teachers who had been able to solve problems that were still a problem for most teachers, to explain to their friends how to solve the problem. At the end of teaching, which is the last 20 minutes of learning, the researcher provides an evaluation that must be done.

\section{Observation Results.}

After the worksheets that directed the teacher to prepare the Minimum Completeness Criteria (KKM) were distributed, the teachers seemed enthusiastic in working on the worksheets. In working on the distributed worksheets, there was no teacher looking to the left or right or other activities, all of them were engrossed in working on the distributed worksheets. In the implementation of working on the worksheet, it appears that there are teachers who experience obstacles in completing questions to their closest friends, but there are also teachers who experience obstacles in working on the worksheets and directly ask the researchers.

From the evaluation results given after being corrected by the researchers, the following results were obtained: Of the 29 existing teachers, 12 teachers got a score of less than $50 \%$, while 17 teachers had scored above the completion limit, this means that $58.62 \%$ of the teachers have been able to properly prepare the Minimum Completeness Criteria $(\mathrm{KKM})$ 
4. Reflection.

By looking at the weak points that occur in some teachers regarding the concept of compiling the Minimum Completeness Criteria (KKM), it is necessary to hold a basic explanation for teachers who experience obstacles by utilizing friends who have understood the concept of compiling the Minimum Completeness Criteria (KKM) to explain it. Furthermore, the researchers recorded teachers who had more abilities and were able to convey the material they mastered to their friends. It is necessary to form small groups consisting of 5 teachers to collaborate in learning and be led by teachers who have more abilities and are able to convey the material they master.

(c) Description of Cycle II.

\section{Planning.}

In the planning of the second cycle, the researcher plans the following actions:

1) Make small groups consisting of 5 teachers and each group is led by a teacher selected from teachers who have more abilities and are able to lead.

2) Make lesson plans for small groups that are used for teaching for 90 minutes.

3) Make 2 worksheets that are used for group discussions

4) Planning evaluation tools used to measure ability teacher.

\section{Implementation of Actions.}

As planned, the researcher carried out the second cycle of action on Saturday, June 5, 2021. The second cycle of action began with an explanation to the teacher about the procedures to be carried out in small group learning. The researcher divides groups of 4 teachers and determines the leader of each group, then the teachers gather according to their respective groups. After the students have gathered with their groups, the researcher distributes worksheets to be discussed together from each group, when the teacher starts discussing the researcher goes around to note the mistakes made by the group to be guided and take notes on the passive teachers so that the group can be actively invited.

After the time specified on the worksheet runs out, the researcher asks group representatives to present their work and other groups are asked to respond to what has been presented, on this occasion the researcher guides the discussion and together with the teacher formulates answers. On Saturday, June 5, 2021, the teacher is given an evaluation of mastery of the material for the preparation of the Minimum Completeness Criteria (KKM) within 1 lesson hour or 40 minutes.

\section{Observation Results}

In the implementation of the second cycle, it was very clear that the teacher was very enthusiastic in doing group assignments, all the teachers seemed active with the group in completing the worksheets given by the researcher.

During the discussion of the material given by one group to be responded to by another group, sometimes it can be seen that there are differences in the thinking patterns of each individual in conveying the problem-solving ideas given. 
Based on the evaluation that was carried out after being corrected, the results were in accordance with the criteria for achieving the expected results because of the 29 existing teachers all scored above the minimum completeness limit, so that the percentage of teachers who had been able to prepare the Minimum Completeness Criteria (KKM) was 100\%.

\section{Reflection}

From the results of the evaluation given for 1 hour of lessons or 40 minutes, it turns out that 29 teachers have been able to get a score above the criteria limit, but mistakes made by the teacher are still visible due to the teacher's lack of thoroughness in work. However, the activity of the teacher as a whole has been as expected by the researchers, as evidenced in working on the worksheets in this group $100 \%$ have been active in discussing the worksheets given.

b) Inter-Cycle Description.

Based on the results of the implementation of the action from monitoring the initial state to the implementation of the action in cycle II, it can be described as follows:

Table 1.

Percentage of achievement from the initial cycle, cycle I and cycle II No Indicator Percentage achieved Beginning of Cycle I Cycle II

\begin{tabular}{clccc}
\hline \multirow{2}{*}{ No } & \multicolumn{1}{c}{ Indicator } & \multicolumn{3}{c}{ Percentage achieved } \\
& & Initial & Cycle I & Cycle II \\
\hline 1 & Ability in preparing KKM & $10 \%$ & $58,62 \%$ & $100 \%$ \\
2 & Ability to work on worksheets & - & $58,62 \%$ & $100 \%$ \\
3 & $\begin{array}{l}\text { Activeness in the discussion of } \\
\text { worksheets }\end{array}$ & - & $50 \%$ & $100 \%$ \\
\hline
\end{tabular}

\section{Discussion}

From the table between cycles above, it appears that the results of each indicator that must be mastered by the teacher after being given action have increased. In cycle I, researchers tend to help in the form of theoretical, passive observer teachers, because almost all teachers have not set minimum completeness criteria, for teachers who have made minimum completeness criteria tend to be made as-is, sometimes imitating teachers in other schools. Meanwhile, in the second cycle, the researcher and the teacher actually participated together in practicing setting the minimum completeness criteria. Teachers are asked to be more active and serious (not casual). At the end of the learning process, each group of teachers presents their work and other groups of teachers criticize and provide input on the results of the teacher's work.

After going through the reflection process, most of the teachers have succeeded in increasing their competence in setting minimum completeness criteria in accordance with the subjects taught. The teacher carefully and deftly chooses how 
to set the minimum completeness criteria and calculates the numbers from starting to settle the minimum completeness criteria for each achievement indicator to the minimum completeness criteria for subjects. In general, the achievement of teacher success in the second cycle has reached a score of 85 or good.

At the beginning of the school year the KKM should be established. No matter how large the number of students who pass the minimum completeness limit, it will not change the teacher's decision in declaring graduation and not passing a lesson. Reference Criteria cannot be changed immediately because of the empirical results of the assessment. Skills, knowledge and attitudes can be developed by learning. There are many ways that can be done both inside and outside the school, for example through a training. According to Widodo (2015), training is a series of individual activities in systematically increasing skills and knowledge so that they are able to have professional performance in their fields.

The success in this research is due to a thorough understanding factor. Hamid in Sudiati (2018) explains that by optimizing teacher understanding through internship coaching in the form of implementation, it is hoped that teachers will discuss, work together and consult actively, creatively. This activity is very helpful for teachers in understanding and being able to apply KKM in accordance with KD, $\mathrm{SK}$, in the syllabus.

In relation to coaching through training, this research is also in accordance with the opinion of experts who state that the purpose of training is to obtain the required level of ability in their work quickly and economically and develop existing abilities. So that the brand's performance on the current task is improved and they are prepared to accept greater responsibilities in the future. (Armstrong in Sudiati 2018).

The activities of teachers in determining the KKM increased, although at first they still had many shortcomings and were reluctant to participate in the training, but after knowing that there were still many shortcomings and needed to be corrected, after the researchers positioned themselves as resource persons according to their request, they explained various shortcomings and explained the instructions to complete them. , they become more enthusiastic and eager to strive to develop their own complete and systematic criteria as they show in the corrective actions in cycle II (Khasanah, 2019).

\section{Conclusion}

A teacher must always improve his professional abilities, knowledge, attitudes, and skills continuously according to the development of science and technology. To achieve these three competencies, schools must carry out coaching for teachers through training, workshops, PKG, discussions, and supervision either by the principal or supervisor. This is done periodically so that the competence and insight of teachers, especially MTs teachers in the Labuhan Batu Regency area increase at any time in accordance with the development of science and technology. Based on the results of the study, it can be seen that there is an increase in teacher 
competence in determining minimum completeness criteria which can be seen from the graphs of cycle I and cycle II. This means that training activities have a positive impact on increasing teacher competence in determining completeness criteria.

\section{References}

DiPaola, M., \& Wagner, C. A. (2018). Improving instruction through supervision, evaluation, and professional development. IAP.

Khasanah, S. (2019). “Upaya Peningkatan Kinerja Guru dalam Menetapkan Kriteria Ketuntasan Minimal Melalui Workshop".Jurnal Bangun Rekaprima. 5 (1).52.

LPPKS. (2011). Supervisi Akademik; Materi Diklat calon kepala sekolah; Jakarta: LPPKS.

Mispandi, M., \& Widayati, A. (2021). Implementation of Sociocultural Education in Facing The Industrial Revolution 4.0 in Madrasah Aliyah (MA) NW Pancor. Edunesia: Jurnal Ilmiah Pendidikan, 2(1), 113-124.

Peraturan Menteri Pendidikan Nasional Republik Indonesia Nomor 22 Tahun 2006 tentang Standar Isi, Jakarta, 2006.

Peraturan Menteri Pendidikan Nasional Republik Indonesia Nomor 23 Tahun 2006 tentangStandar Kompetensi Lulusan, Jakarta, 2006.

Peraturan Pemerintah Nomor 19 Tahun 2005 tentang Standar Nasional Pendidikan, Jakarta: Fokus Media.

Samidi. (2019). Framework Pembelajaran Pendidikan Kewarganegaraan Abad 21. Yogyakarta: UNY Press.

Setiyadi, B., \& Rosalina, V. (2021). Kepemimpinan Kepala Sekolah dalam Meningkatkan Kinerja Guru. Edunesia: Jurnal Ilmiah Pendidikan, 2(1), 75-84.

Sudiati, T. (2018). “Peningkatan Kinerja Guru Dalam Menetapkan Kriteria, Ketuntasan Minimal Melalui Workshop". Jurnal Kajian Teori dan Praktik Kependidikan. 3 (2). 235 236.

Undang-Undang Nomor 20 Tahun 2003 tentang Sistem Pendidikan Nasional, Jakarta:Fokus Media.

Wahyu, W. (2020). Concept of Supervision of Learning Process in Increasing the Quality of Education Results in Madrasah. International Journal of Nusantara Islam, 8(1), 67-77. 
Widodo, E. (2015). Manajemen Pengembangan Sumber Daya Manusia. Yogyakarta: Pustaka Pelajar.

Zaini, M. F., \& Syafaruddin, S. (2020). The Leadership Behavior of Madrasah Principals in Improving the Quality of Education in MAN 3 Medan. Jurnal Iqra': Kajian Ilmu Pendidikan, 5(2), 95-106. 